\title{
Carrie Andersen
}

The University of Texas at Austin, US.

candersen@,utexas.edu

\begin{abstract}
In this article, I argue that the first-person shooter video game, Call of Duty: Black Ops II, reflects the U.S. military's transition as it reimagines the soldier's role in war. In the age of drone technology, this role shifts from a position of strength to one of relative weakness. Although video games that feature future combat often "function as virtual enactments and endorsements for developing military technologies," Black Ops II offers a surprisingly complex vision of the future of drones and U.S. soldiers (Smicker 2009: 107). To explore how the game reflects a contemporary vision of the U.S. military, I weave together a close textual reading of two levels in Black Ops II with actual accounts from drone pilots and politicians that illuminate the nature of drone combat. Although there are moments in Black Ops II in which avatars combat enemies with first-hand firepower, the experience of heroic diegetic violence is superseded by a combat experience defined by powerlessness, boredom, and ambiguous pleasure. The shift of the soldier from imposing hero to a banal figure experiences its logical conclusion in Unmanned, an independent video game that foregrounds the mundane, nonviolent nature of drone piloting. Instead of training soldiers to withstand emotionally devastating experiences of death and violence first-hand (or to physically enact such violence), games like Black Ops II and Unmanned train actual and potential soldiers to tolerate monotony and disempowerment.
\end{abstract}

\section{Introduction}

The year is 2025. The screen flashes images of futuristic military technology: four-legged crawling machines that spray bullets at enemies from behind thick armor; tiny, unmanned quadcopters that nimbly dodge hostile fire; massive stealth unmanned airships that weave through the air to assassinate their targets. Over this montage, a retired military operative laments what he sees as unfortunate changes in military strategy: "Technology got stronger, but we got weaker. We built computers, robots, whole unmanned armies and no one ever asks, 'What happens when the enemy steals the keys?'”

The answer to his question is soon apparent. The montage shifts to visions of Los Angeles attacked by hundreds of tiny drones, explosions coursing through skyscrapers, political rallies led by an unknown villain. What follows is a frantic collage of images of soldiers attacking these machines from a variety of vantage points - behind the control stick of a jet, on the ground with a hand-held gun, in armored vehicles. Only rarely do these soldiers confront human enemies: the enemy is all-too-powerful technology.

So goes the video trailer for the single-player campaign of Call of Duty: Black Ops II, developed by Treyarch and released in 2012, of the wildly popular Call of Duty videogame series. In 2025, a character named Raul Menendez, a Nicaraguan drug lord, plans to hack into America's military computer network to take control of the nation's drones, which he will release against cities worldwide in hopes of both killing thousands of innocent people and inciting a war between China and the United States. Working 
against Menendez's efforts are U.S. operatives, one of whom, David Mason, the player controls throughout much of the game. Although Black Ops II features branching storylines - the ending varies depending on which paths a player takes during certain missions - the overall narrative highlights the dangers that arise from advanced military technologies. But those dangers, as Black Ops II reveals, do not solely emerge from the destructive capacity of that technology: they arise from the increasingly tenuous position of the contemporary U.S. soldier.

In this article, I argue that Black Ops II exemplifies the U.S. military's transition as it reimagines the soldier's role in war in the age of drone technology. The U.S. soldier shifts from a position of strength and valor to one of relative weakness and ennui. Although, according to Josh Smicker (2009), video games often "function as virtual enactments and endorsements for developing military technologies" due to the military's involvement in consulting on game development and to the military's efforts to train and recruit soldiers through games, Black Ops II offers a surprisingly ambiguous and complex vision of the future of drones as surveillance and military tools and of the future of soldiers themselves (2009: 107).

After discussing the theoretical linkage between diegetic actions (that is, in-game actions) and emotion, I present a close reading of two key levels within Black Ops II that suggest that the game does not fully trumpet the value of drone technology to U.S. foreign policy efforts as Smicker (2009) predicts. Nor does the game solely proffer well-trafficked myths of soldierly heroism that both draw aspiring recruits into military service and circulate in political discourse and popular media to establish soldiers as national icons of valor and strength (Faludi 2007; Shyles and Hocking 1990). My reading of these levels reveals that although there are moments in which avatars combat enemies with first-hand firepower, that experience of heroic violence is superseded by a drone-laden combat experience defined instead by impotence, boredom, and ambiguous pleasure. I argue that the emotional experiences that Black Ops II elicits correspond to and reflect the experiences of the contemporary U.S. soldier. The game reflects the uneasy powerlessness of the soldier in the real world, who is often confined to a chair behind a computer screen, controlling machines that are more powerful and efficient than he or she could ever be. My reading of the game suggests that drones do not only dehumanize victims through gazing upon and enacting grotesque violence against them: they dehumanize soldiers by confining the scope of their actions and their power in combat. While Black Ops II offers moments of pleasure when players can enact violence first-hand or operate drones through their avatars-drone power is often striking to witness and to operate in the game - that pleasure is wedded to the more precarious notion of machine strength against human weakness.

I close with a discussion of the future of surveillance and military life beyond the initial gesture that Black Ops II makes towards reimagining the U.S. soldier against the tradition of soldier-heroes. This shift of the soldier from imposing hero to a banal figure experiences its logical conclusion in Molleindustria's Unmanned, an independent video game that almost completely excises opportunities for mythic, vivid violence from the narrative. Instead, Unmanned requires players to delve deeply into the mundane life of the drone pilot, complete with morning commutes and workplace drama. Although free from the traumatic aura of the battlefield, this pilot experiences a new form of trauma: the absence of vivifying violence and the crushing reality of the desk job. While deviating from the heroic soldier icon marks a departure from war-based video games, that construct may paradoxically be beneficial for the U.S. military due to the demands of drone-based warfare. Instead of training soldiers to withstand emotionally devastating experiences of violence first-hand or to physically enact such violence, games like Black Ops II and Unmanned train actual and potential soldiers to tolerate monotony and uneasy disempowerment through repetitive clicking and through ceding control to the machine. 


\section{Methodology and Background}

Before my analysis of drone combat within Black Ops II and outside of it, I first offer a brief explanation of what drones actually are. Drones within the world of Black Ops II fall into two categories: fully autonomous unmanned systems piloted by automated computer systems, and remotely-piloted vehicles that physically lack a pilot in the cockpit but are controlled by a human agent elsewhere. These diegetic vehicles have analogues in the real world of drone combat. U.S. soldiers and tactical engineers likewise control remotely-piloted vehicles that they observe through a screen by using a controller, just as a gamer might use to play a video game like Black Ops II (see Figures 1 and 2).

But drones in the real world are hardly mere vehicles for virtual adventures. These unmanned machines perform weighty tasks, from collecting intelligence to attacking individuals, purportedly with astonishing precision. Since 2008, the Obama administration has created "dozens of secret facilities, including two operational hubs on the East Coast, virtual Air Force cockpits in the Southwest and clandestine bases in at least six countries on two continents" as part of a growing governmental drone network (Miller 2011). John Brennan, director of the CIA, has defended the administration's use of drones, arguing, "we conduct targeted strikes because they are necessary to mitigate an actual ongoing threat" (Tau 2012).

Black Ops II constitutes a powerful example of the outward bleeding of drones from the world of Brennan's CIA and the armed forces' bases. One of many commercially successful games in the Call of Duty series, which sold over 100 million copies before the release of Black Ops II, the game yielded over $\$ 1$ billion in sales over the first fifteen days following its release (Richmond 2011; Agnello 2012). Although these numbers do not indicate how many individuals have played the game or the single-player drone-based campaign - many players solely participate in multiplayer melees over the internet - they do suggest that the game is widely distributed and played. Whatever ideologies and anxieties Black Ops II reveals about drones and human soldiers are reaching a vast and significant audience of players, making this case study a compelling means of exploring the transitional status of the U.S. soldier.

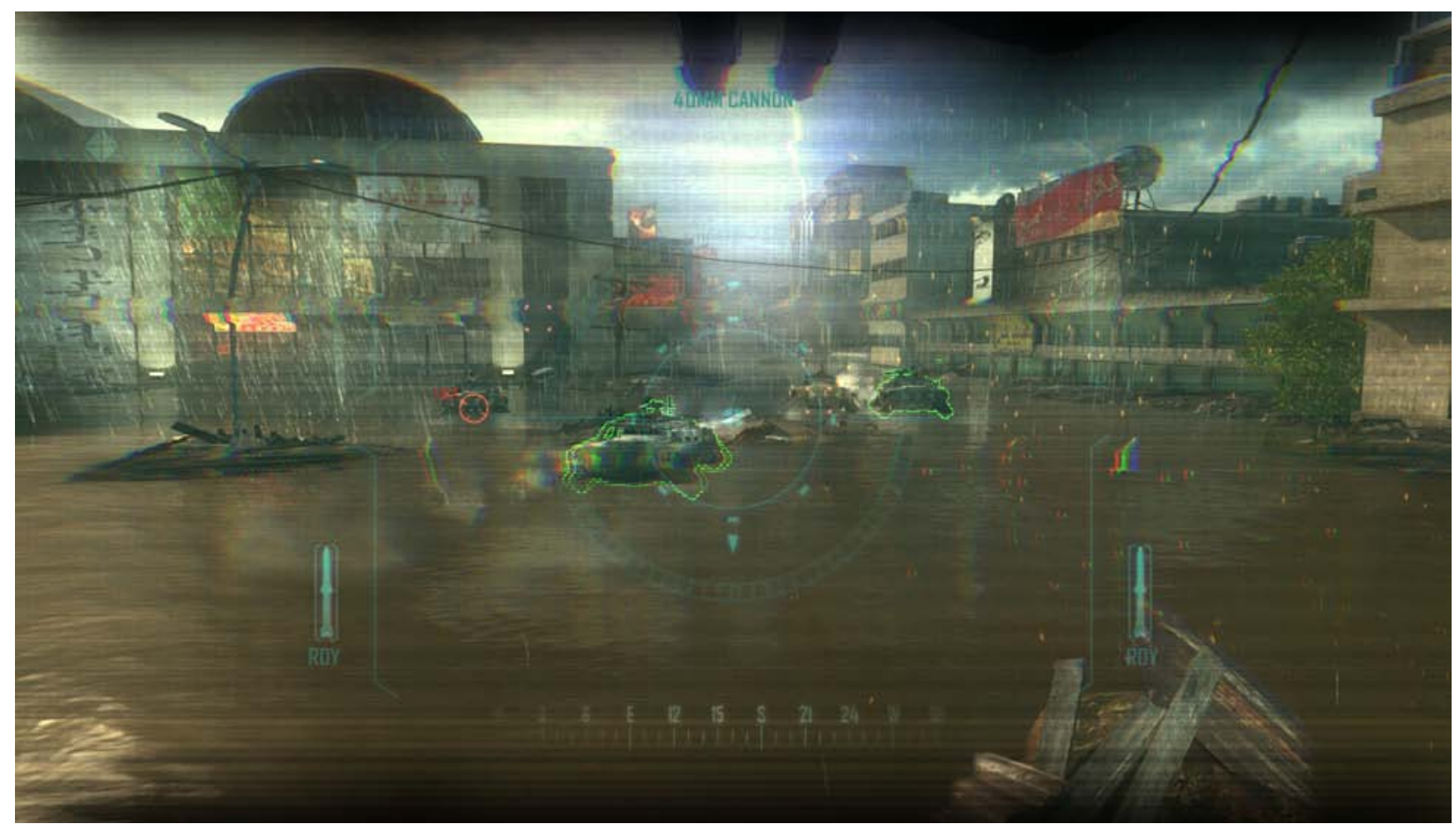

Figure 1. Screenshot from Black Ops II. The player pilots an unmanned aerial vehicle through the air. 


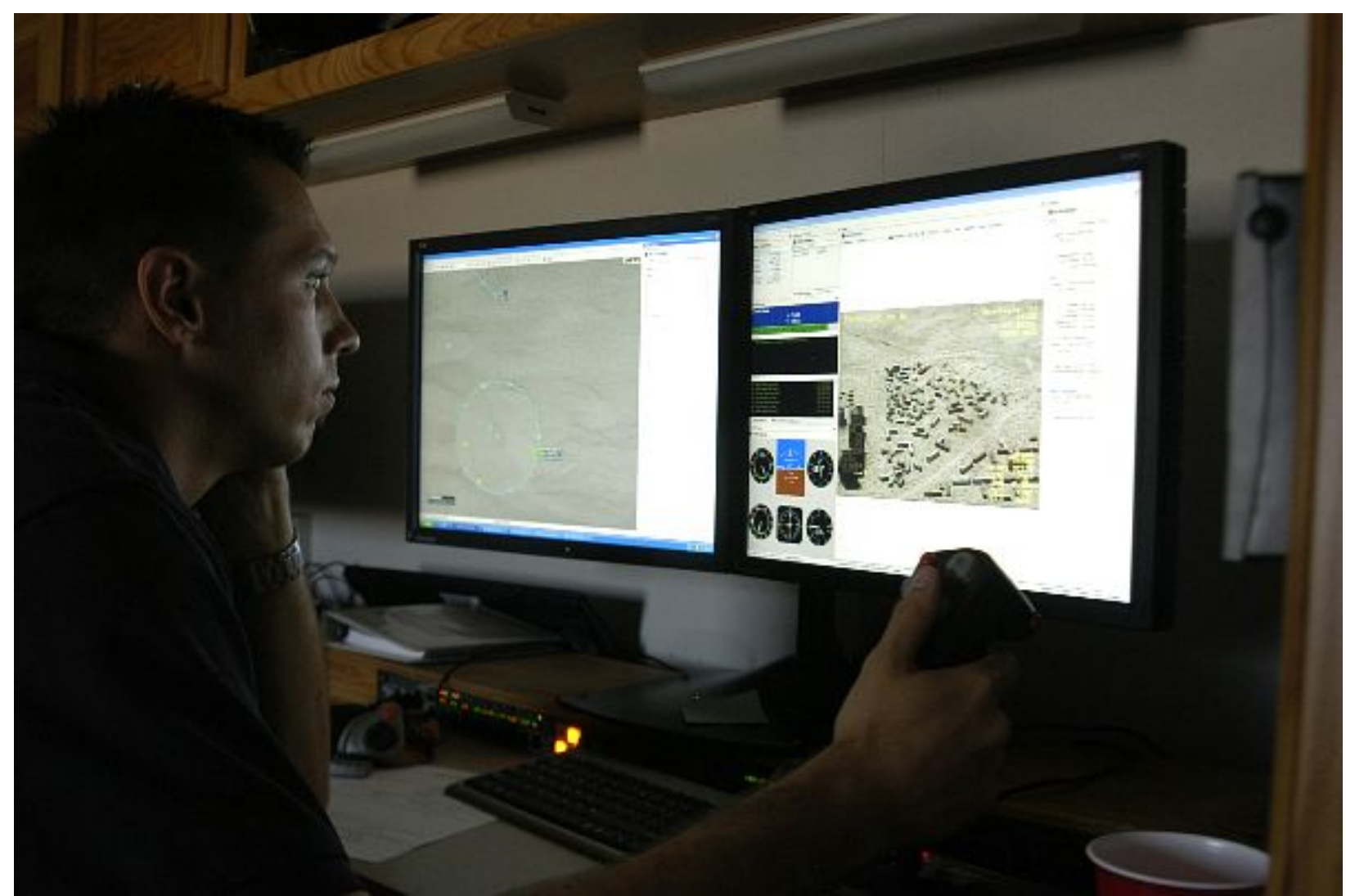

Figure 2. An advanced tactical systems engineer for Boeing views a training range through the camera of a ScanEagle unmanned aerial vehicle, a vehicle designed for reconnaissance and surveillance. (Photograph by Cpl. Michael P. Snody. The United States Marine Corps. June 19, 2006. Yuma, Arizona.)

The U.S. soldier has historically been imbued with a mythic aura of heroism, a figure of human agency rather than a pawn of military technology. This article interrogates that heroic icon as it collides with the tedious and tragic realities of $21^{\text {st }}$ century joystick warfare. As Kathleen McClancy (2013) describes, the figure of the U.S. soldier-hero has propagated since the nation's inception, defined by a propensity to enact regenerative violence, a myth explored by historian Richard Slotkin that links violent acts to both national renewal and self-creation. McClancy (2013) notes that the long-standing figure of national heroic agency rooted in violence was challenged during the Vietnam War era through televisual representations of warfare as mundane, conducted by fleets of bored soldiers. She notes, however, that in spite of this fracturing of the soldier-hero icon, "the next twenty years after the Vietnam War would see a determined effort on the part of both the government and American society, particularly in film, to rehabilitate this cultural monster and thus to transmute his violence, once more, toward a narrative that supported American mythologies of the regenerative hero" (McClancy 2013: 65). In McClancy's (2013) estimation, political and cultural representations of the heroic soldier figure remain potent in film, television, and other video games. I argue here, however, that Black Ops II represents a departure from that post-Vietnam War trend by challenging the soldier-hero icon. ${ }^{1}$

In interrogating a parallel departure from the soldier-hero iconography that McClancy (2013) finds in media coverage of the Vietnam War, my analysis builds on Matthew Cousineau's (2011) call for attending to "patterns of surveillance in the relationship between the military industrial-complex and entertainment"

\footnotetext{
${ }^{1}$ In popular media and political discourse, the soldier-hero figure is described not only as valorous, but as hyper-masculine (see Faludi (2007), Adams (2008), Donald and MacDonald (2011), or McClancy (2013) for examples of this conflation). Although this is a line of inquiry worth pursuing — particularly because the only avatars one can operate in Black Ops II are male- my analysis focuses instead on soldiers' agency and emotional experiences of combat.
} 
by exploring the relationship between drone technology and U.S. soldiers within the narrative of Black Ops II (2011: 517). Black Ops II is a useful case study in exploring the relationship between soldiers and machines both due to its enormous popularity and the fact that the single-player campaign game revolves around the use of drones in combat and surveillance. Within Cousineau's (2011) broad framework, I emphasize potential emotional responses to the single-player campaign that emerge from the game's procedural rhetoric. Procedural rhetoric, defined by Ian Bogost (2007), emphasizes how "rule-based representations" and actions have persuasive and ideological power like visual or written rhetoric (2007: ix). Although Bogost's (2007) framework does not foreground players' experiences or emotions, I maintain that a game's rule system invites an emotional gaming experience as players are confronted with both obstacles and opportunities to exercise diegetic power. Players might be frustrated when playing a difficult level, empowered by an avatar's strength, confused by a game's myriad procedural possibilities, or delighted when circumventing stringent rules of gameplay. My analysis thus also draws upon the earlier work of Torben Grodal (2003), who contends that diegetic actions are inextricably linked to emotional experience: "video games... allow 'the full experiential flow' by linking perceptions, cognitions, and emotions with first-person actions" (2003: 132). The linkage Grodal draws between action and emotion thus invites a line of questioning that explores the emotional experience of player agency. How powerful are avatars within a particular game? What can those avatars do? What can't they do? How does a player's agency, or lack thereof, evoke or stunt a particular emotional response? How does the experience of having or lacking agency feel in moments when drones literally fly into the narrative? And how do these diegetic experiences in the world of Black Ops II parallel the real life experiences and emotions of drone pilots in the U.S. military?

Before pursuing empirical research that draws on the experiences of U.S. soldiers and citizens who play Black Ops II, I am starting a line of inquiry in the tradition of cultural studies analysis by offering a close reading of the procedural rhetoric that characterizes the campaign. ${ }^{2}$ An interdisciplinary lens which offers both a textual reading of the game and an analysis of the game's position within the broader military system pinpoints the convergence between diegetic experience and military action that Cousineau (2011) discusses. The rest of my analysis thus engages with these questions by examining key moments in the single-player campaign in which players confront drones and how those moments express a conflicted vision of U.S. soldiers.

Specifically, my analysis focuses on the relative capacities of humans and machines to enact violence within the game. Although an in-depth analysis of every moment of Black Ops II where drones are foregrounded is unworkable in an article of this length, a close reading of two levels where the player substantially interacts with drones - whether controlling them or being shot at by them-usefully sheds light upon the U.S. soldier-machine relationship that the game puts forth. I then explore the diegetic construction of that relationship alongside accounts of modern warfare from drone pilots, other members of the armed services, politicians, veterans, and academic researchers. This article weaves together those diegetic and non-diegetic threads that, together, illuminate how Black Ops II reveals the troubled state of the U.S. soldier in the real world. To avoid confusing these lines of inquiry within my analysis, I refer to "the Black Ops II world" and "the real world," respectively.

\section{Demoting the Soldier-Hero: Machine Strength, Human Weakness}

In this section, I first explore how Black Ops II reveals the relative weakness of humans against the increasingly sublime power of machines, thereby disrupting the icon of the soldier-hero. My analysis first focuses on a level of the game based in Pakistan. The player controls David Mason, a U.S. operative

\footnotetext{
2 This article comprises an initial foray into representations of drones in popular media that I am exploring in my dissertation on drone technology.
} 
moving through a flooded, battle-ridden city in 2025 in pursuit of intelligence on Menendez. ${ }^{3}$ Accompanying him is a small band of fighters, including his partner Mike Harper and two four-legged unmanned vehicles called CLAWs (or Cognitive Land Assault Weapons) (see Figure 3).

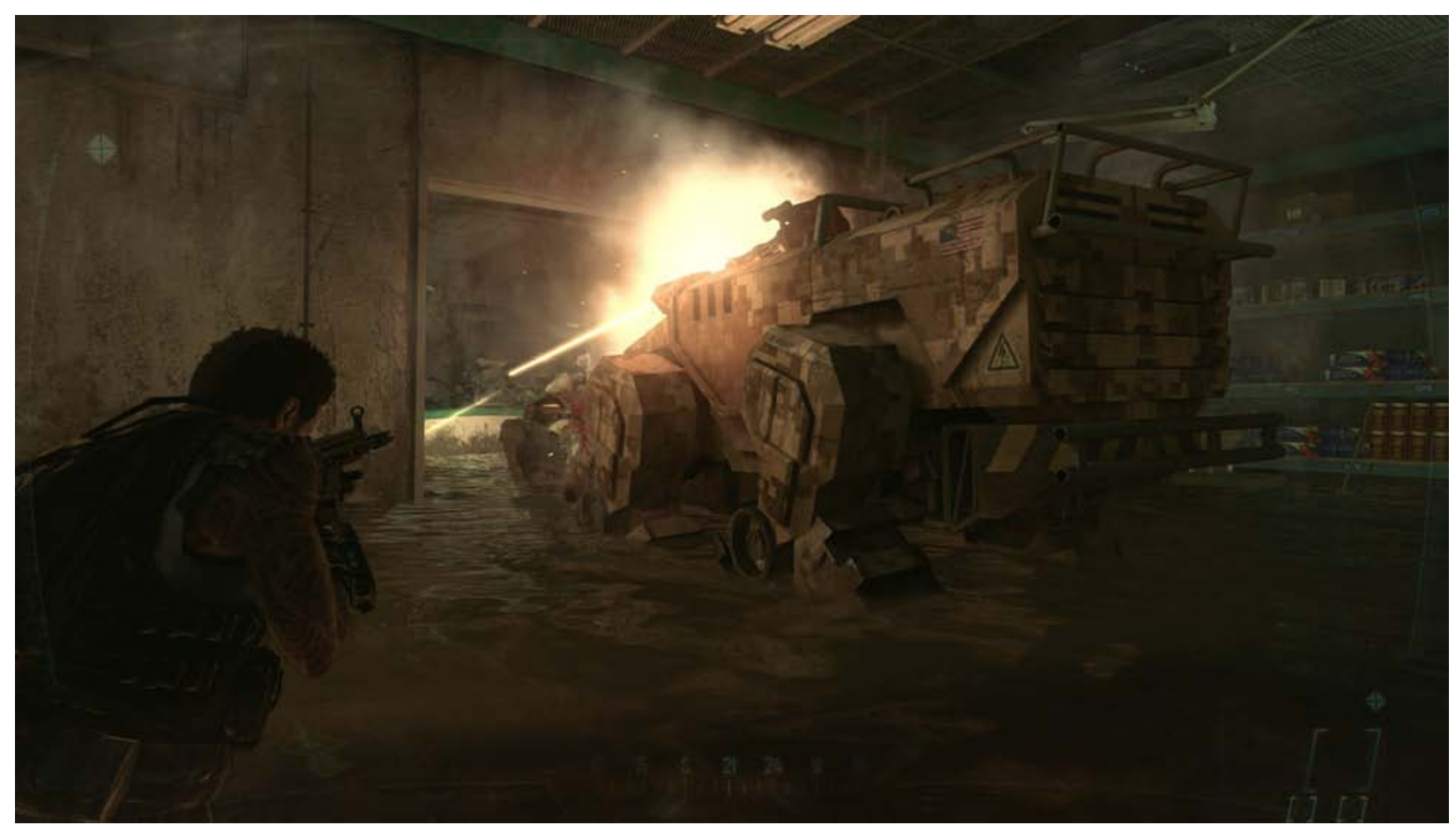

Figure 3. Screenshot from Black Ops II. One of the CLAWs fires at enemy soldiers through a doorway, flanked by Harper.

Enemy soldiers immediately fire at Mason and his fellow operatives, but the CLAWs, named Maximus and Brutus, display their grotesque power. More destructive than any individual soldiers, Maximus and Brutus spray bullets at the enemy so quickly that players only hear an unsettling hum rather than individual shots. But these CLAWs are not completely within the player's control. The player cannot control when the bullets are fired, although one can tell the vehicle where it should walk and that it should aim in a particular area (the CLAW's camera technology, through which players briefly glimpse at the beginning of the level, can recognize human enemies and will target and follow those enemies with its gun within that broad area). The contrast between the CLAWs' power to kill and Mason's is stark, not only because his gun is weak, but because the player is restricted from fully controlling the CLAWs' firepower.

Before the gunfire ceases, a soldier alerts Mason to a flying enemy drone that approaches to eliminate the U.S. troops, its firepower far surpassing that of any enemy soldier that players have shot at thus far. Harper soon shouts at Mason to direct the CLAW's spray of bullets at the drone. No individual soldier has sufficient firepower to destroy the drone. Regardless of how much players shoot at the drone, its armor is virtually impenetrable. Without Maximus or Brutus on attack, the drone can kill Mason with remarkable rapidity. Within Black Ops II there is no escape from its firepower once the avatar is spotted and fired upon, an experience that also parallels drone violence in the real world. As Tyler Wall and Torin Monahan suggest, drone-based violence depends upon "intense aerial surveillance of bodies and movements," merging being seen by this technological gaze with almost inevitable injury in both the game and real life (2011: 242).

\footnotetext{
${ }^{3}$ Because the only characters that can be controlled in Black Ops II are male, I refer to soldiers in Black Ops II solely with male pronouns.
} 
The disparity in power between human and machine is jarring. Nonetheless, the flood waters prove to be too difficult for the CLAW machines to traverse, and they malfunction. Mason and the surviving U.S. operatives are left to fend for themselves in the streets of Pakistan, which are littered with enemies. Players can pick off these enemies one by one, but the act of killing is a much slower process without the CLAWs. And a player is almost completely powerless to act against others' drone technologies without similarly powerful drones, like Maximus and Brutus. In this moment in Black Ops II, players relinquish some power to the drones. This decline in power parallels real world uneasiness about who soldiers are becoming that are beginning to seep into public discourse from servicemen themselves-particularly where the physical experience of warfare is concerned.

First-hand accounts from real world drone pilots reflect anxieties similar to those that this moment of Black Ops II puts forth. A drone pilot student in the Air Force named Kelly (drone pilots are often only referred to by first name and/or rank in media reports for security purposes) who "grew up wanting to be a fighter pilot" but whose vision was too poor for the job, laments the "cultural divide" between drone pilots and fighter pilots who sit in cockpits of real planes (Martin 2011a). Another student named Aaron notes some hostility as well: "You see people in a conventional aircrew that wonder why we get to wear the flight suits even though we don't leave the ground, why do we need flight physicals, why do we get incentive pay" (Martin 2011a). Within the Air Force, tensions rest in part upon the notion that drone pilots do not need to be as powerful as fighter pilots, nor are they similarly confronted with life-threatening situations. Even though "the Air Force has been working to bridge the divide between these two groups of fliers," uneasiness remains as to whether drone pilots constitute real pilots, particularly in the eyes of fighter pilots (Martin 2011a). The power disparity between humans and the CLAWs within Black Ops II communicates a parallel form of uneasiness in the real world, where soldiers' strength is diminished due to the presence of drones on the battlefield.

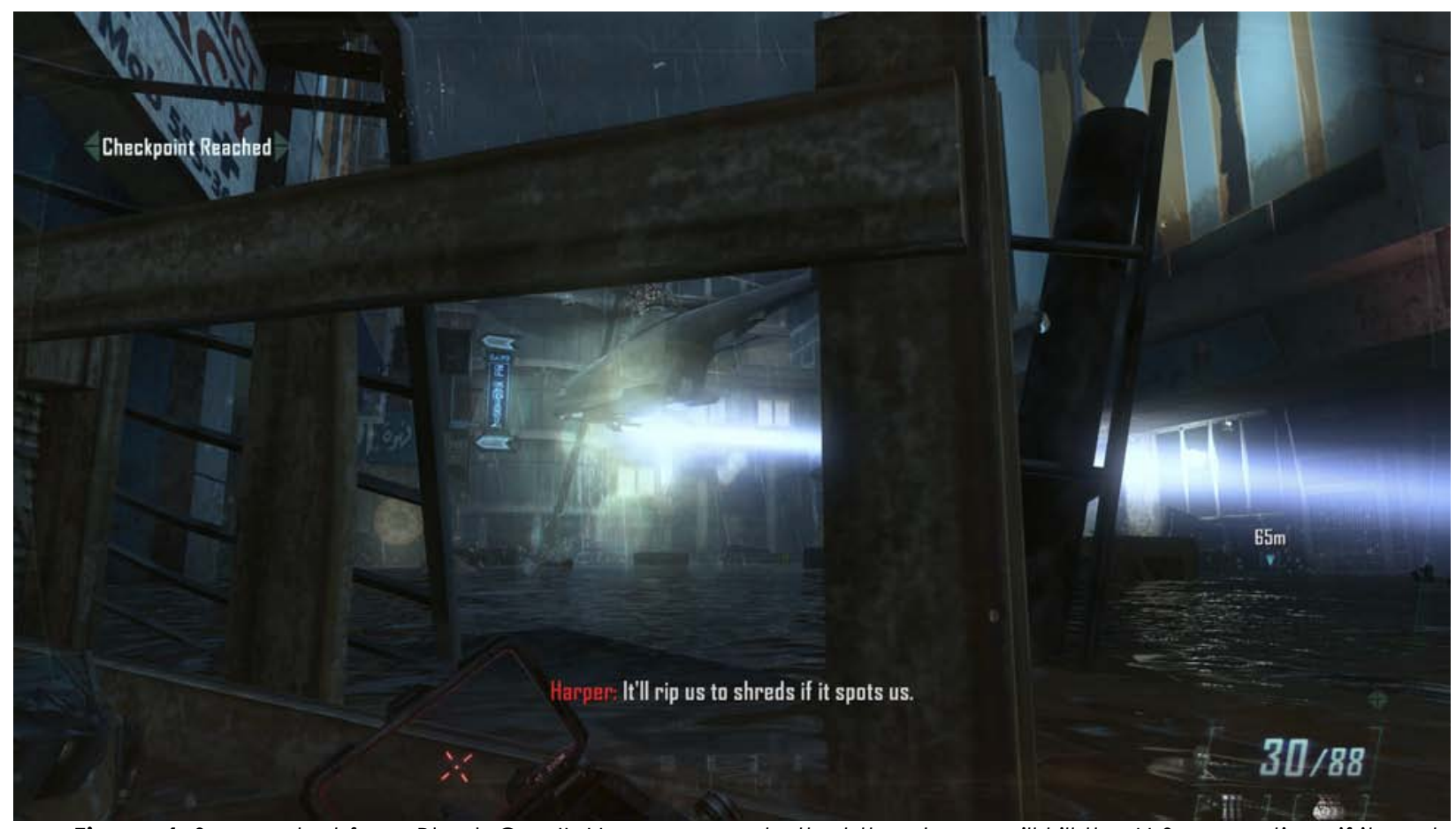

Figure 4. Screenshot from Black Ops II. Harper remarks that the drone will kill the U.S. operatives if it spots them with its searchlight or hears them move through the water too quickly.

A second stage of the same level in Black Ops II requires Mason and Harper to avoid being spotted by drone helicopters outfitted with cameras and spotlights as they navigate Pakistan's streets. These 
helicopters were deployed to patrol the flooded streets and pick off Pakistani looters with surreal efficiency, suggesting that the drone is an autonomous vehicle coded to assassinate hostile targets with nary a pilot behind it. And the drones can also target Harper and Mason. To pass through their patrol area, a player must guide Mason quietly through the shadows so as not to visually or aurally alert the drone to his presence, which would result in his swift destruction (see Figure 4). These drones possess such offensive and defensive strength that an individual solder's firepower is frustratingly useless against them. Firing the gun only alerts the drones to Mason's presence and death ensues.

Despite Frédérick Gagnon's (2010) argument that Call of Duty games "trivialize violence and invite players to cherish and fetishize weapons," and despite the commonly held assumption that these games and others like them highlight the prowess of the soldier-hero, the narrative moment I describe above reinforces the relative impotence of soldiers' firepower against the ever-watchful drones. This construction also belies the tendency of the first-person shooter game genre to center the individual soldier as a powerful political agent (Gish 2010; Tanine 2010). In this level, the soldier is less heroic and more subservient, pressed quietly into the shadows by this technology's powerful surveillance capabilities. By forcing Mason into submission (and by restricting the kinds of diegetic actions that players can undertake, as shooting at the drone means it will hear, see, and kill the avatar immediately), the level illustrates human soldiers' weakness in exacting destruction. This diegetic moment calls to mind Wall and Monahan's discussion of the real world effects of the drone's technological gaze: "drone systems necessarily objectify, and most likely dehumanize, people targeted by them," thanks to their surveillance powers (2011: 246). Yet the act of retaliating against the machine brings death upon the soldiers of Black Ops II, suggesting that violent resistance to drone power is ultimately futile-unless one has a drone on his side. Players are meant to silently skirt the drone's vision, hardly an act of courage and heroism that popular narratives of the military have offered in other media (Faludi 2007; Takacs 2012; Gish 2010). The soldier-hero, in this moment of Black Ops II, is nowhere to be found.

A potent example of the ways that the soldier-hero icon is similarly disempowered when drones enter the battlefield can be found in a real world conflict over how to acknowledge the efforts of drone pilots to conduct surveillance and enact violence for the U.S. military. In February 2013, U.S. Defense Secretary Leon Panetta announced the creation of the "Distinguished Warfare Medal" that would recognize "the extraordinary achievements that directly impact on combat operations, but that do not involve acts of valor or physical risk that combat entails" (Shanker 2013). Shortly after Panetta's announcement, elected officials and members of the armed services critiqued the move because the medal's rank would be higher than those received in combat and in life-threatening situations (Terkel 2013). Twenty-two senators sent a letter to Panetta's successor, U.S. Defense Secretary Chuck Hagel, urging him to reconsider the status of the Distinguished Warfare Medal: "Placing the Distinguished Warfare Medal above the Bronze Star and Purple Heart diminishes the significance of awards earned by risking one's life in direct combat or through acts of heroism" (Office of Senator Joe Manchin 2013). Veterans expressed similar sentiments. John Bircher, a spokesman for the Military Order of the Purple Heart, said veterans were concerned that the medal a drone pilot would earn trumped a medal earned in actual combat, like the Purple Heart: "These guys work relentless hours, and are dedicated and good at what they do, but it's completely different from the hardships of serving in combat and being on the battlefield" (Freking 2013). Shortly after the medal's announcement, the Defense Department announced its cancellation, instead offering a special designation for drone piloting achievements.

This dispute reveals among military officials a sharp distinction between drone piloting and on-the-ground military combat rooted in a soldier's physical experience, paralleled in Black Ops II. For critics of the Distinguished Warfare Medal, physical combat constitutes a more legitimate mode of military action than drone piloting. Implied in these critiques is the notion that drone pilots do not perform the physical activities that soldier-heroes ought to perform. The iconic soldier is not solely defined by his experience of life-threatening situations: he or she also bravely responds in kind by firing back at enemies, an 
opportunity that is stunted within Black Ops II when the CLAW units take over or when Mason must not fire at a powerful drone. Ultimately, the conflict over the medal boils down to the notion that the rise of the drone in itself chips away at the long-standing myth of the U.S. soldier-hero due to the absence of a regenerative physical combat experience. The fact that such critiques come from servicemen and public officials alike reveals the continued potency of the soldier-hero icon in the national imaginationespecially when the icon is threatened. Black Ops II communicates that same anxiety about soldierly valor when soldiers in the game first cede their power to machines and thwart their own opportunities for bravery.

Paradoxically, fusing soldierly heroism with bravery in life-threatening situations foreshadows another potential threat to the soldier-hero that U.S. troops have not yet confronted: what happens to the icon when soldiers encounter an enemy's enormously destructive drones that inevitably cause a loss of life, as Black Ops II presages? In other words, what happens to the soldier-hero when his violence is transformed from a regenerative experience and display of retaliatory courage to one that only invites evisceration? Although the U.S. military has not yet confronted this issue directly-fleets of powerful hostile drones have not, to the public's knowledge, been deployed against U.S. troops producing a massive bloodbath-Black Ops II questions whether the life-threatening and valorizing effects of physical warfare remain essential components of the soldier-hero icon when the enemy is a machine that is too formidable to be destroyed by a human. In moments when our protagonists Mason and Harper must avoid being seen or heard by drones to survive the flooded Pakistani streets, human-driven violence (i.e. firing a gun) becomes an act of incompetence or desperation rather than an act of heroism. In this case, the soldier-hero's value and valor as legitimized through a life-threatening experience is disrupted because he has little opportunity to effectively retaliate and exercise the first-hand heroic violence that McClancy (2013) describes. Black Ops II ultimately parallels and anticipates anxieties within the military about how physical disempowerment reflects tension about what it means to be a soldier in the present and future, thanks to powerful machines on the battlefield.

\section{The Seduction of Machine Power}

Encounters with drones in this level in Pakistan in Black Ops II expose real world concerns about the status of drone pilots against the trope of the soldier-hero. Yet I provide here an alternate reading of the same level that acknowledges the seductive power of machines. Like other cultural forms that project a variety of emotion-laden assessments of the future of military technology, from apocalyptic anxieties to totalizing and pleasurable notions of technoutopia, Black Ops II offers a polysemic vision of the future. Daniel Dinello's (2005) exploration of fear and adoration of technology within popular culture is instructive. In addition to foreshadowing apocalypse, futuristic tales can reflect our "contemporary dream of a heavenly techno-utopia ruled by robotic gods" (2005: 35). Perhaps, then, these drones reflect a desire to relinquish human control to the strength and perfection of the machine. In the Black Ops II universe, however, yielding to the drone's power-however pleasurable - is less of a dream and more of a seductive nightmare, one that hinges upon a begrudging acknowledgement of machine power and relative human weakness.

As troubling as the displacement of the individual soldier is, Maximus and Brutus also offer a brief sense of relief by efficiently spotting and eliminating enemy soldiers without putting the player's avatar at risk or without requiring precise targeting with a gun. The pleasure of such sophisticated surveillance technologies being deployed on the soldier's behalf can enable players to enjoy the rest of the level without getting bogged down in a perpetual gunfight, a feature in line with Anders Albrechtslund and Lynsey Dubbeld's (2005) assessment of the ways in which surveillance technologies can afford amusement. That joy dovetails with some narratives from real world drone pilots in the U.S., according to Peter Singer: describing his experience fighting in the Iraq War from a base in Qatar, a drone pilot remarks, "It's like a video game. It can get a little bloodthirsty. But it's fucking cool" (2009: 332). 
The gameplay of Black Ops II often offers an experience similar to Singer's (2009) enthusiastic drone pilot: a player can control a drone equipped with a camera and colossal firepower. After Menendez spots Harper and Mason in Pakistan, they are no longer safe within the shadows and must violently retaliate against enemy soldiers and drones. But their own manpower is insufficient to ensure their safe escape. Instead, the player tracks and kills enemies through a CLAW unit, outfitted with a grenade launcher and a flame thrower and/or machine gun turret. All action is glimpsed through the CLAW's camera lens (see Figure 5). The capacity to cause such destruction is emboldening. Mason and Harper are safe while the CLAW units are in use - neither character can die while the player is using the CLAWs - and the enemies are no match for the machine's firepower. True security is only to be found when drones are deployed.

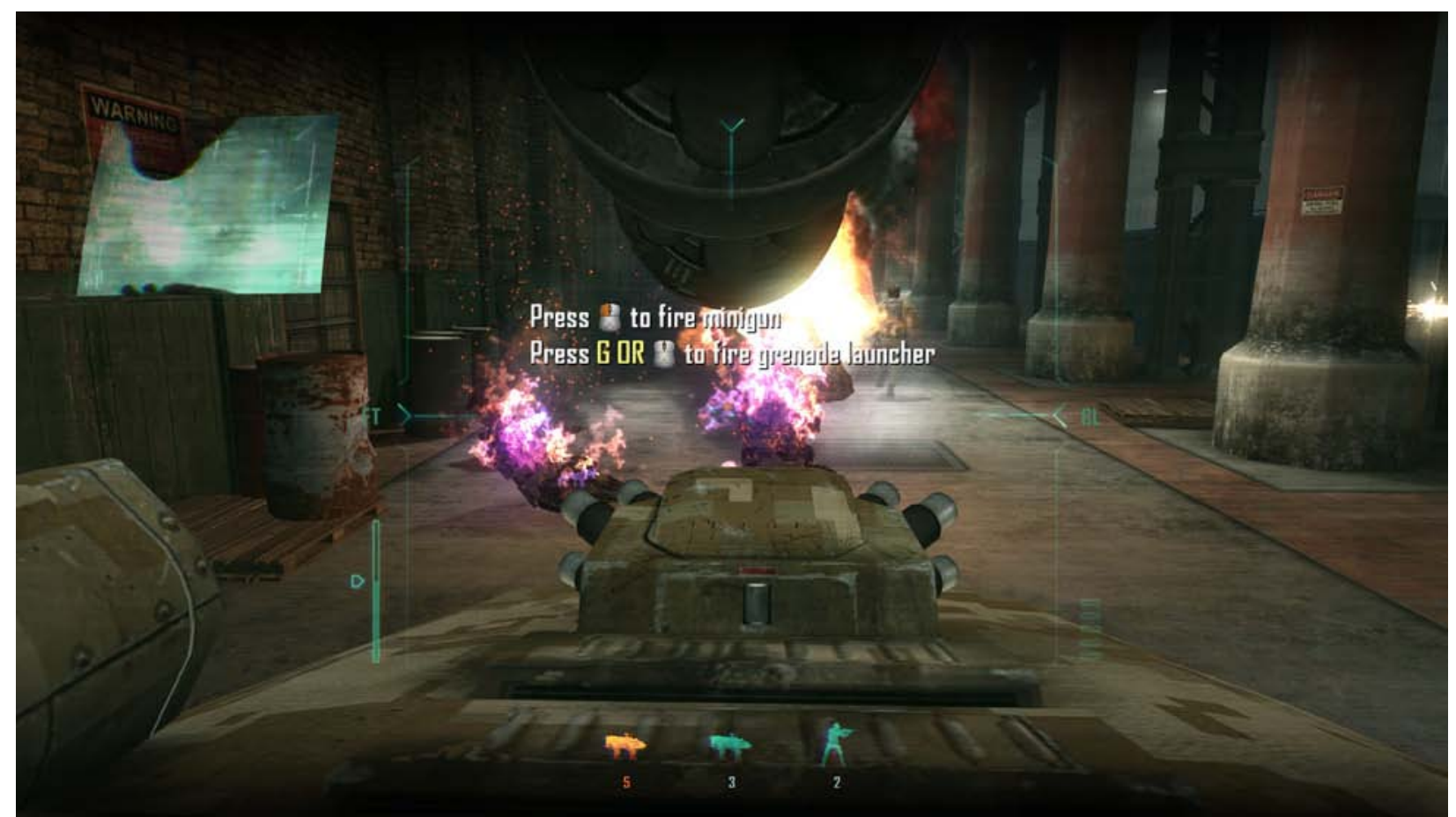

Figure 5. Screenshot from Black Ops II. The player views enemies through the lens of the CLAW unit's camera.

As Harper and Mason escape, the player has the option to pilot an aerial drone equipped with rockets that can be fired at enemies blocking their path. The player glimpses the ground through the same cameras that the MQ drones were using to spot looters in the flooded Pakistani streets. Hand-held guns are insufficient here: the drone's rockets are necessary to clear a path for the two operatives. Controlling that immense firepower against targets seen from above can offer a pleasurable sense of strength, even if the power emerges from a machine rather than a human. Ultimately, however, that pleasure depends upon a simultaneous acknowledgement of the constraints of human power against machines that seem to have no limits. With the joy of a machine's power comes the parallel anxiety of human weakness.

This decentering of the soldier-hero trope that occurs alongside the jarring excitement of operating a drone is surprising for a war game. David Nieborg (2009) and Frédérick Gagnon (2010) both point to the striking one-sidedness of war games within the military-entertainment complex that overwhelmingly endorse military action, particularly with respect to the righteousness and strength of U.S. soldiers. Harrison Gish (2010), for example, notes that Spark Unlimited's Call of Duty: Finest Hour, a World War II-based game in the Call of Duty franchise released in 2004, positions U.S. forces as "both fundamentally heroic and tied to a Western individualist ethos," placing heroism squarely within the individual soldier (2010: 170). Yet perhaps no game has yielded as much scholarly attention as America's Army, a game 
created by the U.S. Army and first released in 2002 to trumpet pro-military ideologies and to excite potential young recruits about enlisting. Scholars have critiqued the game for its propagandistic tendencies and its uncomplicated ethics that laud the heroism of U.S. soldiers but fail to challenge any aspect of military intervention (Nichols 2009; Nieborg 2009).

Although Black Ops II broadly glorifies violence and U.S. military dominance like America's Army and other first-person shooter games do, it is nonetheless surprising that the individual soldier within Black Ops II occupies such a precarious position in part because the military has strong relationships with video game developers and publishers. Military consultants like retired Lt. Colonel Hank Keirsey work with developers within the Call of Duty series to ensure the games' authenticity in its representations of combat. Keirsey's goal is to ensure that veterans' gritty stories of courage are told to those who might not otherwise think about military history, a motivation that falls in line with well-trafficked tales of heroic human soldiers (Thier 2010). The vaunted soldier-hero can also be found in the structural convergence between Activision - the publisher of the series - and the military. Activision founded the Call of Duty Endowment to help "service members transition to civilian careers after their military service," the consequence being that some revenues from Call of Duty game sales are funneled into aid for veterans (Call of Duty Endowment n.d.). Furthermore, when Call of Duty: Modern Warfare 2 was released in 2010, the company donated around 3,000 copies to members of the U.S. Navy through the Call of Duty Endowment (Gonzalez 2010). Yet in spite of the military's material and ideological support of the soldierhero, and in spite of the game's general endorsement of the U.S. military's violent actions, Black Ops II nonetheless makes significant breaks with a cadre of war games that uncritically elevate the individual soldier as a formidable heroic agent instead elevating machines over humans.

\section{The Boredom of Modern Warfare}

Having explored both dystopian projections of human weakness and seductive representations of powerful technology, I focus here on machine-enabled boredom within Black Ops II. The game's narrative continues in Yemen with a level in which the player controls a man named Farid. An undercover operative with ties to the United States, Farid has infiltrated Cordis Die, the radical movement that Menendez runs. As a result, the player acts as enemy soldier who must combat U.S. operatives as well as their drone technology, which includes small quadrotor helicopters (that is, helicopters with four rotors) called MQ-27 Dragonfires that, like the CLAWs, spot and fire at enemies autonomously. These Dragonfires are nuisances. The player's gun is powerful enough to destroy them with a few well-placed shots, although the units are agile and often hard to see (see Figure 6, overleaf). These machines are not as powerful as the drone helicopters Mason first confronts in the streets of Pakistan. Although they do cause damage, Farid's death is not a foregone conclusion if the Dragonfire spots him and fires.

Farid is soon captured by Menendez's men, however, and after he is killed, the player switches from operating Farid to Mason, charged with killing as many members of Cordis Die as possible and capturing Menendez. The Dragonfires, formerly harmful nuisances, now become helpful. These drones can go where Mason cannot, and players can tell them to advance to the general vicinity ahead of Mason to clear the enemies blocking his path with a quick tap of a button on his watch (see Figure 7, overleaf).

Yet this pleasure and relief can also shift to an unexpected sense of boredom that belies the visual and aural excitement of explosions and Dragonfires zipping past Mason. Doris Rusch (2008) reminds us of the value of diegetic violence instigated by players, suggesting that "in games, the visceral joy of first-hand experiences is strongly related to the experience of agency.... experiencing agency also means viscerally enjoying the outcome of a certain action, such as watching the monster you have just hit with a grenade explode into bits" (2008: 29). But if a player sends these remote-controlled agents to deftly wipe away a slew of individual enemies, the game can become at once easier and less exciting. The actions players can take as soldiers, like shooting a single enemy after searching for him, aiming, and firing a few times, are 
relatively inconsequential. These drones can enable finishing the level with greater efficiency and safety. Their gaze over the landscape is complete and infallible. But their powers of surveillance that separate soldier and enemy coupled with their mediated killing denies the pleasure of enacting what has been the central facet of the first-person shooter game since the genre's inception, where first-hand acts of violence are sources of power and pleasure.

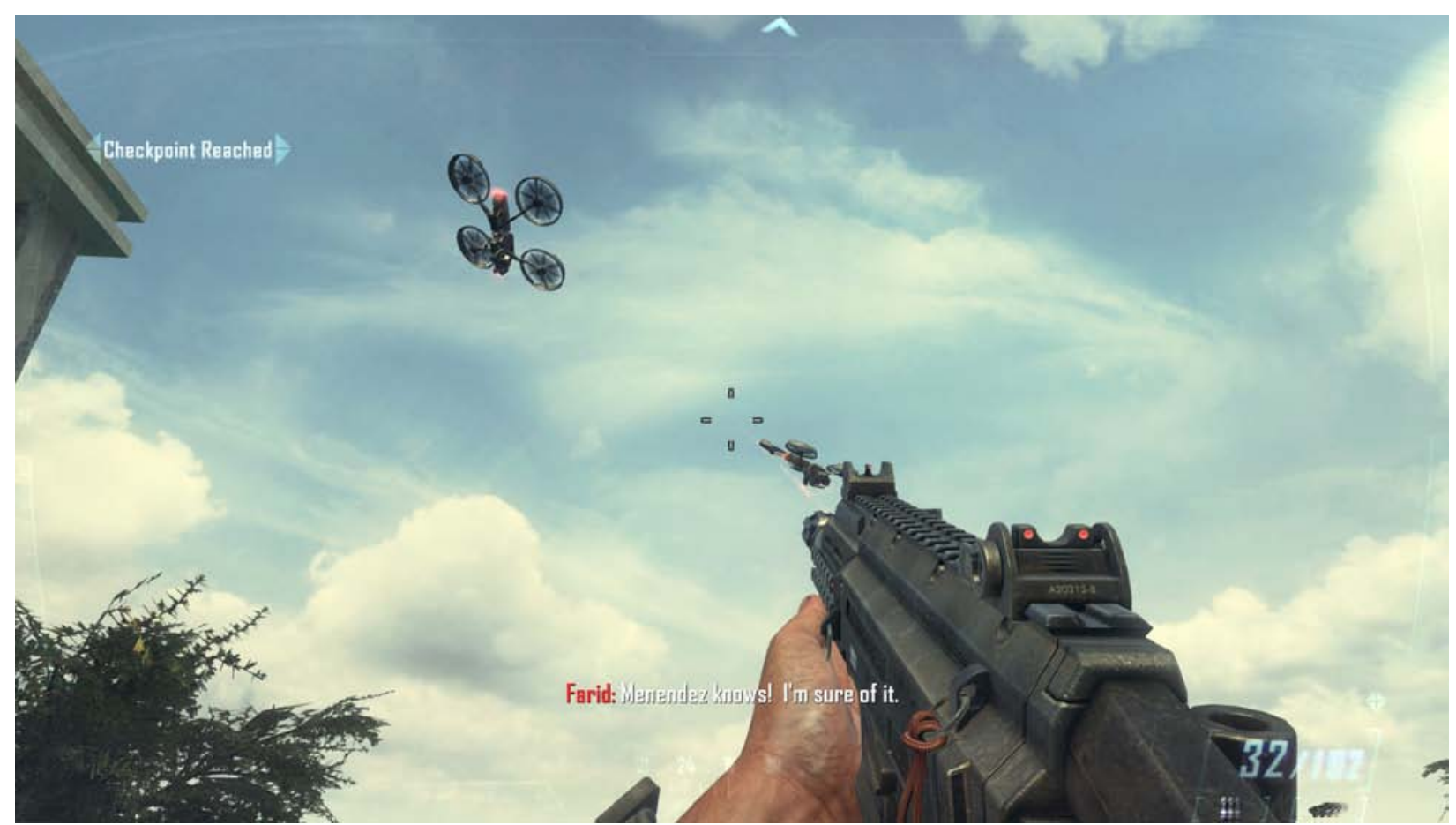

Figure 6. Screenshot from Black Ops II. Farid aims at one of two Dragonfires while expressing concern that his cover has been blown.

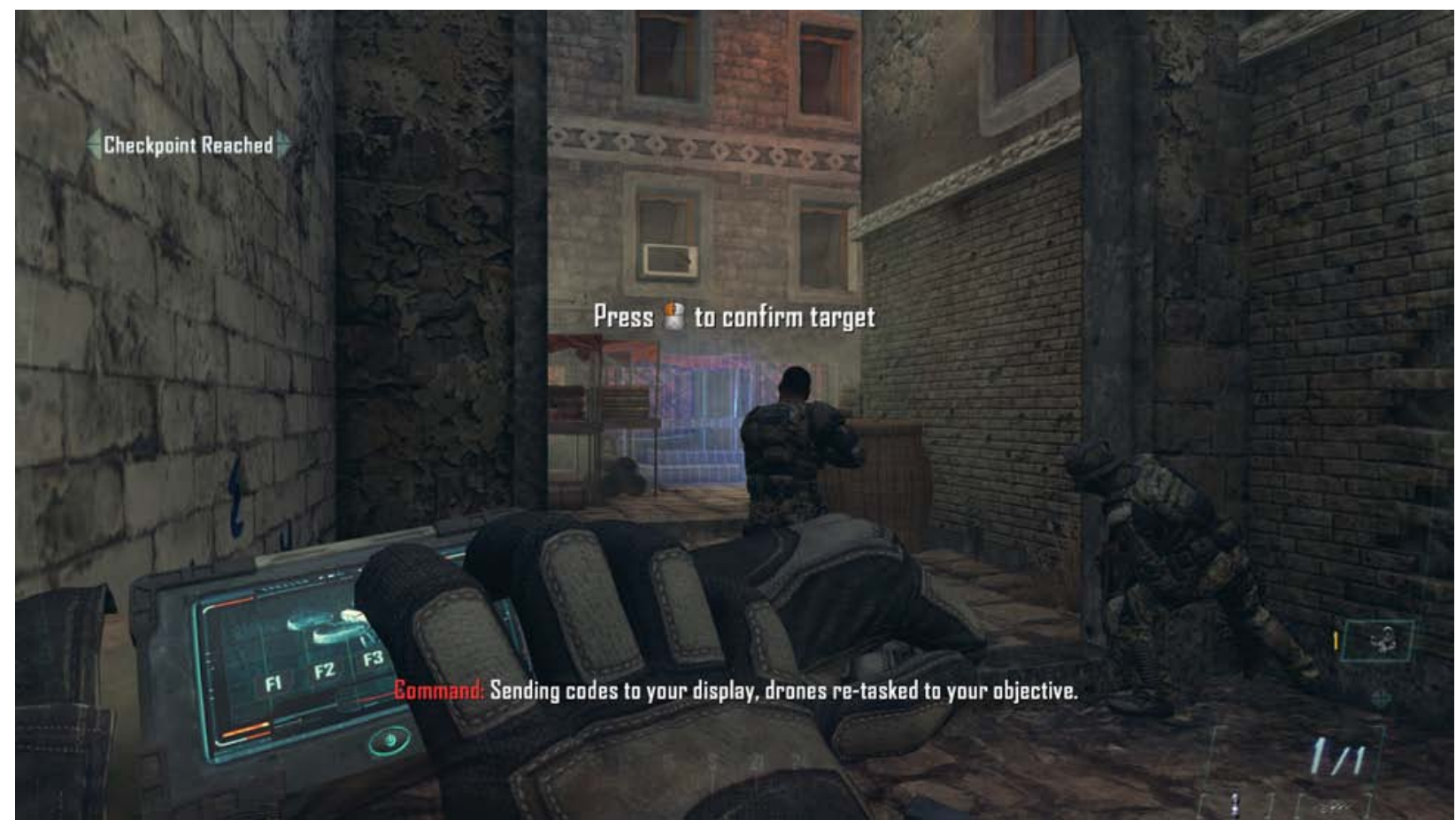

Figure 7. Screenshot from Black Ops II. Mason sends a group of Dragonfires to attack nearby enemies. 
Displacing killing from soldier to drone may also have more significant effects than forestalling pleasure and inciting boredom. Timothy Melley positions the violent act as one that not only affords pleasure, but reinforces one's identity, since one way to respond to a loss of individual power "is a violent attempt to conserve individual identity and volition" (2000: 347). But in Black Ops II, there is a chasm between directing the Dragonfires and picking off each enemy with a gun, however inefficient the latter act may be. Because the violence the player enacts is mediated by a drone, whatever possibility there is to reclaim individual agency and to experience pleasure through violence is partially blocked. Displacing the killing mechanism from the avatar to a drone stands suggests an inability to enact significant violent actions compared with the drones (thanks in large part to the sophistication of their targeting abilities) and stunts the pleasure of the outcome of that diegetic action.

This drone-laden level that merges shocking moments of violence with moments of boredom calls to mind Sianne Ngai's (2005) discussion of stuplimity, defined as "the bringing together... of sharp, sudden excitation and prolonged desensitization, exhaustion, or fatigue" (2005: 271). Although Ngai (2005) refers to our inability to fully comprehend philosophical totality, her framework is also useful in exploring human physical limitations that hamper gazing broadly over the battlefield. Those limitations are displayed starkly in Black Ops II, and results in a kind of paralysis that links overwhelming excitement with tedium.

That experience of boredom and shock is not limited to the world of Black Ops II, or to the world of video games: representations of warfare in the real world similarly position conflict as replete with unexciting experiences. McClancy describes how U.S. televisual coverage of the Vietnam War focused on the routine experiences of soldiers: "Clips following bomber pilots, for example, emphasized the repetitiveness of their missions: wake up, fly over North Vietnam, drop bombs, head back to the base or carrier for dinner" (2013: 56). Characterizing even acts of violence as mundane meant that war was depicted "as a common job and soldiering as no more glamorous or heroic than commuting from the suburbs in a grey flannel suit" (McClancy 2013: 57). U.S. soldiers' experiences in Vietnam, however harrowing they actually were, were presented to the public as dull moments in a humdrum life. For McClancy (2013), that representation disrupts the long-standing representation of the soldier-hero in the nation's discourse.

These media representations of war as mundane during the Vietnam era anticipate contemporary anxieties over the relationship between losing control over violence to increasingly powerful machines. If drones can do what troops and operatives cannot - for example, they can safely watch and kill potential enemies thanks to their precise totalizing gaze-perhaps combatants will be relegated to dull desk jobs behind screens instead of the battlefield. Speaking of the U.S. soldier's experience, Singer (2009) describes how contemporary warfare has "shifted for many soldiers from the battle space to Office Space. For a new generation, 'going to war' doesn't mean shipping off to some dank foxhole in a foreign land to dodge bullets. Instead, it is a daily commute in your Toyota Camry to sit behind a computer screen and drag a mouse" (2009: 329).

Drone pilots in the real world often grumble about the tedium of their jobs. One pilot laments, "I'm overpaid, underworked, and bored"; the relative safety of his new position is no match for the excitement of piloting a bomber over Afghanistan (Hurwitz 2013). Aeronautics engineering scholar and former fighter pilot Mary "Missy" Cummings breaks down a typical surveillance task for a pilot: "You might park a UAV over a house, waiting for someone to come in or come out, and that's where the boredom comes in" (Chu 2012). The dull nature of the job is no anomaly. According to her study, "90 percent [of drone pilots] report moderate to total boredom" with their jobs (Cummings 2012). Drone piloting has little in common with the Saving Private Ryan experience that many of us think of when we think of military combat. The potentials of sophisticated surveillance technologies have reformed what war and violence feel like and what war requires of soldiers, as Black Ops II illustrates. Heroism in modern war may no 
longer involve storming an enemy stronghold from the trenches. It may instead only involve avoiding hand cramps from clicking a mouse long enough to eradicate distant enemies.

This uneasy and unexciting future of soldiers' activities in the drone age that Black Ops II presents is baldly exposed in Unmanned, a game released in 2012 by Molleindustria, a left-wing organization that produces short-form free online games to "call for the radicalization of popular culture" in its critiques of issues like alienated labor, the fast food industry, the oil industry, and religious intolerance (Molleindustria n.d.). Unmanned satirizes the relentless action and violence of first-person shooters and the heroic myths surrounding warfare itself by instead presenting combat through the eyes of a drone pilot. Instead of driving diegetic action through the courageous and violent deployment of heavy artillery, the protagonist of Unmanned is steeped in a mundane world of shaving in the morning, commuting on Route 95 to the drone piloting headquarters, and dealing with stressful personal issues from a workplace crush to a child with a potential ADHD diagnosis (see Figure 8). Here, exercising violence comprises only a miniscule portion of gameplay. The action instead lies in everyday life, navigating "the rather safe, humdrum existence of a modern drone pilot" (Orland 2012).

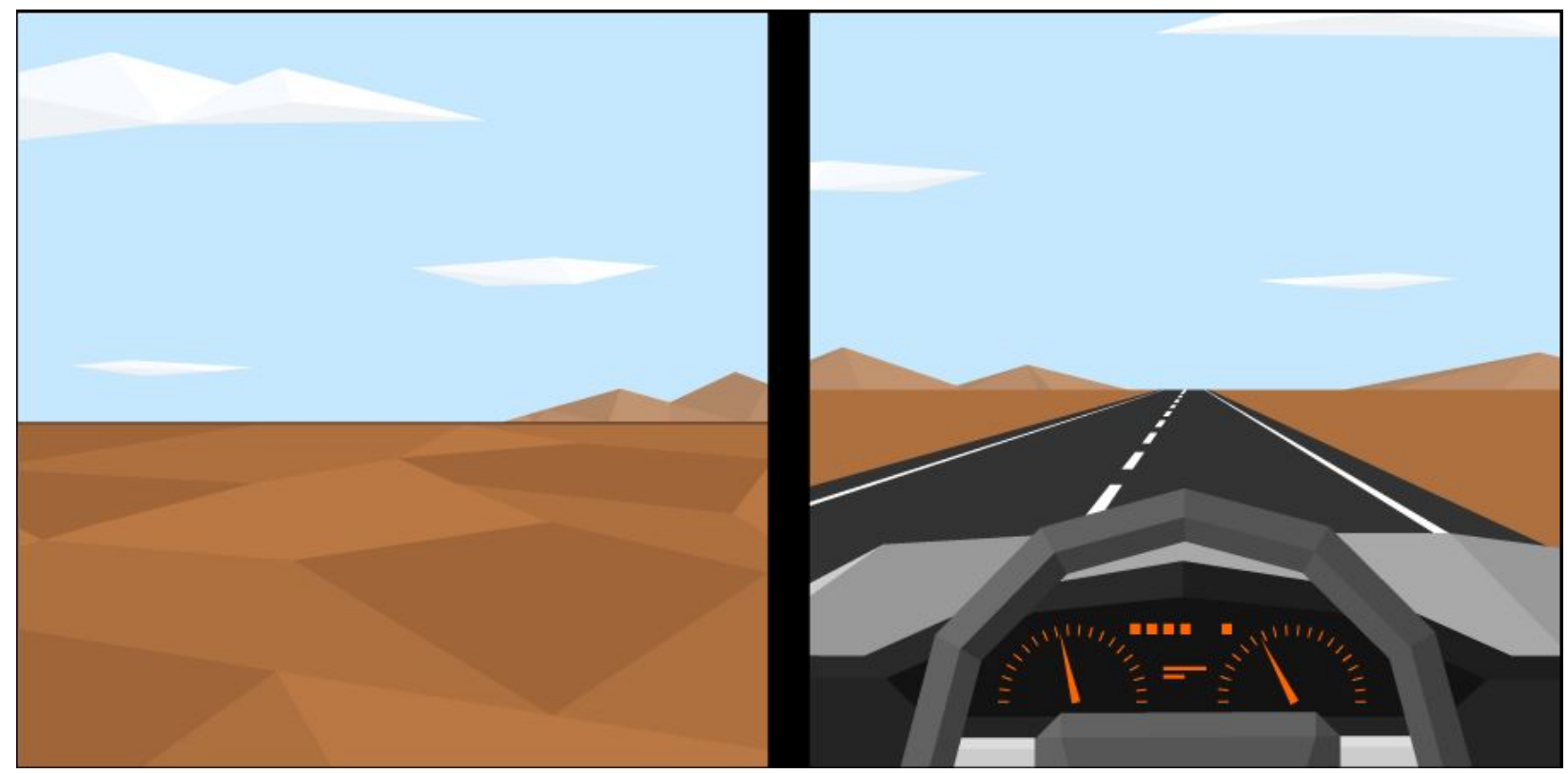

Figure 8. Screenshot from Unmanned. The player must guide a car down Route 95-a straight, unexciting road-to complete this portion of the game.

Drawing a linkage between mundane narrative content and purposefully unexciting gameplay-diegetic actions involve choosing among snippets of dialogue in a choose-your-own-adventure variety of play or, in one case, driving a car on a straight, dull road - suggests a military future bereft of excitement thanks to drones that soldiers can operate with joysticks and buttons. When the pilot arrives to the office in Unmanned, he is charged with simply watching over a target abroad through a drone outfitted with surveillance technologies. Unmanned points to a future in which even the constrained forms of combat that Black Ops II offers are absent from the modern soldier's experience. The possibility of redemptive violence, Unmanned claims, is no longer available to soldiers. Its satire of military heroism and violence, however, blends with an unexpected collusion with the U.S. military's real world recruitment and training efforts. The military has a vested interest in searching for soldiers who can tolerate monotony, as Cummings's (2012) study alludes to. In that vein, one drone pilot remarks that "flying the recon drone is 'kind of like old Atari, pretty basic, point and click"' (Singer 2009: 129). Ironically, Unmanned provides both physical and emotional training for the real life drone pilot's experience of modern warfare, an experience that Black Ops II similarly (and surprisingly) offers. 
But the emotional responses - impotence, pleasure, boredom - that arise from killing individual soldiers with guns versus with drones within Black Ops II do not totally align with the plural emotional experiences drone pilots have in the real world. A Pentagon study of U.S. soldiers found that "switching back and forth" between the dual realities of piloting drones in a war zone and immediately commuting home from the military base was stressful and jarring for many members of the armed forces (Martin 2011b). Moreover, the study found that witnessing or causing death through drones did contribute to some pilots experiencing symptoms of post-traumatic stress disorder. Such a finding corresponds to Wall and Monahan's (2011) discussion of the humanizing potentials of surveillance: "the pilots [of UAVs] may be on the other side of the globe yet nonetheless feel proximate to those with whom they engage. This may create the possibility for a re-personalization of distant, technologically mediated attacks" (2011: 249). Perhaps this sophisticated technological gaze could more readily link killer and victim than we first assume.

Yet at the same time, the Pentagon study positioned emotional responses to drone killing as anomalies, noting that "the authors found limited stress related to a unique aspect of the operators' jobs: watching hours of close-up video of people killed in drone strikes" (Bumiller 2011). Nonetheless, a drone pilot's response to his or her distance from a military target is subjective and contingent, paralleling the pluralistic emotional responses I find in my analysis of Black Ops II and exposing the tensions that characterize the uneasiness of the contemporary U.S. soldier.

\section{Conclusion: The Future of Soldiering, the End of Heroism}

Against popular narratives and U.S. military rhetoric that laud soldiers' heroism and strength, Black Ops II instead centers on the vast surveillance capabilities and violent powers of machines. The game becomes a harbinger of a future of warfare that dehumanizes those soldiers by restricting their scope of violent action and their victims by spotting and killing them with ostensible zeal. Affording players the experience of both deploying and embodying these drones at once enables players to enact a pleasurable form of sublime technological destruction emboldened with the camera's gaze and to nervously feel how vast the gulf is between human and machine capabilities. Although we would expect the game to more clearly endorse military technology and the power of U.S. soldiers based on the precedents set by the Call of Duty series, other cultural products within the military-entertainment complex, and military rhetoric, it offers a surprisingly uneasy future of warfare. Neither human nor machine is afforded a secure position in Black Ops II.

My analysis of Black Ops II also aligns with the potentially problematic ways gaming and drones are becoming increasingly intertwined outside of the game space. This is a trend that Cousineau (2011) similarly calls us to reflect upon, although it is beyond the scope of this project to fully investigate this convergence and its implications. If players learn the skills necessary to pilot drones and conduct surveillance operations through games like Black Ops II, even if the displacement of human soldiers is emphasized, those players may be folded into the increasingly drone-based military-entertainment complex by virtue of enacting the same actions that piloting a drone requires. The soldier-gamer seems to be displacing the soldier-hero due in part to games like Black Ops II that carve out a space for a new kind of soldier to enlist. Singer (2009) explains, for example, that the military uses the same kinds of controllers players use to play video games for drone piloting because Marines already know how to use them. Moreover, according to a U.S. military journal, "The Army will draw on a generation of mindnimble (not necessarily literate), finger-quick youth and their years of experience as heroes and killers in violent, virtually real interactive videos" (Singer 2009: 365). In building a modern fleet, the U.S. military seeks veterans of Halo or Call of Duty rather than aspiring soldiers who immerse themselves in physical training and learning about the strategies of Patton or MacArthur. Consequently, interrogating the ways that games can affectively and physically "train" future soldiers comprises a politically significant realm for future research. 
In the end, the protagonist of Unmanned succinctly diagnoses the tenuous future of the U.S. soldier's experience: "Not exactly the exciting job the posters said it would be, eh?" he grumbles to his boss of his drone pilot gig. "Not everyone has to be the hero," she responds. Unmanned challenges and complicates myth of the superhero soldier by exposing the dullness of drone-based warfare and excising any possibility for heroism in this mode of military action, a concern that Black Ops II anticipates in its juxtaposition of powerful machines against weaker human soldiers. But neither game directly answers the question that might follow from the drone pilot's boss's response: who is the new soldier-hero? What is to become of the national icon that has circulated since the inception of the United States? What is to become of warfare without the potential for traditional soldierly heroism?

By foregrounding an experience of powerlessness, pleasure, and boredom in combat, Black Ops II replicates in its diegetic content the precarious status of the soldier-hero in the U.S. military system. But the game leaves little indication as to who-or what - might fill the soldier-hero's shoes in the nation's future discourse, or how the absence of heroism in combat will impact military culture and the public's willingness to back military intervention. A de-heroized, banal, and boring mode of warfare might make the public less inclined to spill blood overseas in the absence of soldier-heroes on the frontlines-or, perhaps, with U.S. soldiers safely on the joystick end of an asymmetrical drone strike, even more willing to support war.

\section{Acknowledgments}

Enormous thanks to Randolph Lewis, Jeannette Vaught, Emily Roehl, Bart Simon, and Jennifer Whitson, as well as this piece's anonymous reviewers, for their generative and helpful comments on this article.

\section{References}

Adams, Jon Robert. 2008. Male Armor: The Soldier-Hero in Contemporary American Culture. Charlottesville, VA: University of Virginia Press.

Agnello, Anthony John. 2012. Call of Duty: Black Ops 2 beats Modern Warfare 3 to $\$ 1$ billion but... Digital Trends. Accessed November 15, 2012. http:/www.digitaltrends.com/gaming/call-of-duty-black-ops-2-beats-modern-warfare-3-to-1$\underline{\text { billion-but/ }}$

Albrechtslund, Anders and Lynsey Dubbeld. 2005. The Plays and Arts of Surveillance: Studying Surveillance as Entertainment. Surveillance \& Society 3(2/3): 216-221.

Bogost, Ian. 2007. Persuasive Games: The Expressive Power of Video Games. Cambridge, MA: MIT Press.

Bumiller, Elisabeth. 2011. Air Force Drone Operators Report High Levels of Stress. The New York Times. Accessed November 15, 2012. http://www.nytimes.com/2011/12/19/world/asia/air-force-drone-operators-show-high-levels-of-stress.html

Call of Duty Endowment. n.d. About Us. Activision. Accessed July 10, 2013. http://www.callofdutyendowment.org/aboutus/about-code/

Chu, Jennifer. 2012. Driving drones can be a drag. MIT News. Accessed February 25, 2014. http://web.mit.edu/newsoffice/2012/boredom-and-unmanned-aerial-vehicles-1114.html

Cousineau, Matthew. 2011. The Surveillant Simulation of War: Entertainment and Surveillance in the $21^{\text {st }}$ Century. Surveillance \& Society 8(4): 517-522.

Cummings, Mary. 2012. Interview with Ira Flatow. Science Friday. Podcast audio. February 3, 2012. Accessed February 25, 2014. http://www.npr.org/2012/02/03/146350507/drone-technology-reaches-new-heights

Dinello, Daniel. 2005. Technophobia! Science Fiction Visions of Posthuman Technology. Austin, TX: University of Texas Press.

Donald, Ralph and Karen MacDonald. 2011. Reel Men At War: Masculinity and the American War Film. Plymouth, UK: Scarecrow Press, Inc.

Faludi, Susan. 2007. The Terror Dream: Fear and Fantasy in Post-9/11 America. New York, NY: Metropolitan Books.

Freking, Kevin. 2013. Lawmakers, Vet Groups Panning Pentagon's New Medal. Associated Press. Accessed February $24,2014$. http://bigstory.ap.org/article/lawmakers-vet-groups-panning-pentagons-new-medal

Gagnon, Frédérick. 2010. "Invading Your Hearts and Minds": Call of Duty and the (Re)Writing of Militarism in U.S. Digital Games and Popular Culture. European Journal of American Studies, 5(3). Accessed November 17, 2012. http://ejas.revues.org/8831

Gish, Harrison. 2010. Playing the Second World War: Call of Duty and the Telling of History. Eludamos 4(2): 167-180.

Gonzalez, Annette. 2010. \$180,000 Worth of Modern Warfare 2 Units Presented to U.S. Navy. Game Informer. Accessed June 20, 2013. http://www.gameinformer.com/b/news/archive/2010/03/30/180k-mw2-presented-to-navy.aspx

Grodal, Torben. 2003. Stories for Eye, Ear, and Muscles: Video Games, Media, and Embodied Experiences. In The Video Game Theory Reader, edited by M.J.P. Wolf and B. Perron, 129-156. New York, NY: Routledge. 
Hurwitz, Elijah Solomon. 2013. Drone Pilots: Overpaid, Underworked, and Bored. Mother Jones. Accessed June $20,2013$. http://www.motherjones.com/politics/2013/06/drone-pilots-reaper-photo-essay

Martin, Rachel. 2011a. Drone Pilots: The Future of Aerial Warfare. NPR. Accessed February 25, 2014. http://www.npr.org/2011/11/29/142858358/drone-pilots-the-future-of-aerial-warfare

. 2011b. Report: High Levels of 'Burnout' in U.S. Drone Pilots. NPR. Accessed November 17, 2012. http://www.npr.org/2011/12/19/143926857/report-high-levels-of-burnout-in-u-s-drone-pilots

McClancy, Kathleen. 2013. The Iconography of Violence: Television, Vietnam, and the Soldier Hero. Film and History 43(2): 5066.

Melley, Timothy. 2000. Empire of Conspiracy: the Culture of Paranoia in Postwar America. Ithaca, NY: Cornell University Press.

Miller, Greg. 2011. Under Obama, an emerging global apparatus for drone killing. The Washington Post. Accessed November 17, 2012. http://www.washingtonpost.com/national/national-security/under-obama-an-emerging-global-apparatus-fordrone-killing/2011/12/13/gIQANPdILP story.html

Molleindustria. n.d. ABOUT | Molleindustria. Accessed February 24, 2014. http://www.molleindustria.org/blog/about/

Nichols, Randy. 2009. Target Acquired: America's Army and the Video Games Industry. In Joystick Soldiers: The Politics of Play in Military Video Games, edited by Nina B. Huntemann and Matthew T. Payne, 39-52. New York, NY: Routledge.

Ngai, Sianne. 2005. Ugly Feelings. Cambridge, MA: Oxford University Press.

Nieborg, David. 2009. Training Recruits and Conditioning Youth: The Soft Power of Military Games. In Joystick Soldiers: The Politics of Play in Military Video Games, edited by Nina B. Huntemann and Matthew T. Payne, 53-66. New York, NY: Routledge.

Office of Senator Joe Manchin. 2013. Manchin, Rockefeller Bipartisan Group Protect Rank of Purple Heart, Bronze Star. Office of Senator Joe Manchin Press Release. Accessed February 27, 2014. http://www.manchin.senate.gov/public/index.cfm/press-releases?ID=10d1e2ee-b014-4e81-8a0a-c8d6e1a3affd

Orland, Kyle. 2012. Unmanned presents a nuanced, psychological perspective on modern warfare. Ars Technica. Accessed February 27, 2014. http://arstechnica.com/gaming/2012/02/unmanned-presents-a-nuanced-psychological-perspectiveon-modern-warfare/

Richmond, Shane. 2011. Call of Duty: Modern Warfare 3 breaks sales records. The Telegraph. Accessed November 15, 2012. http://www.telegraph.co.uk/technology/video-games/video-game-news/8884726/Call-of-Duty-Modern-Warfare-3breaks-sales-records.html

Rusch, Doris. 2008. Emotional Design of Computer Games and Fiction Films. In Computer Games as a Sociocultural Phenomenon: Games Without Frontiers, Wars Without Tears, edited by Andreas Jahn-Sudmann and Ralf Stockmann, 22-31. New York, NY: Palgrave Macmillan.

Shanker, Thom. 2013. A New Medal Honors Drone Pilots and Computer Experts. The New York Times. Accessed February 27, 2014. http://www.nytimes.com/2013/02/14/us/new-medal-to-honor-drone-pilots-and-computer-experts.html

Shyles, Leonard and John E. Hocking. 1990. The Army’s "Be All You Can Be" Campaign. Armed Forces and Society 16(3): 369383.

Singer, P.W. 2009. Wired for War: The Robotics Revolution and Conflict in the 21st Century. New York, NY: Penguin Group.

Smicker, Josh. 2009. Future Combat, Combating Futures: Temporalities of War Video Games and the Performance of Proleptic Histories. In Joystick Soldiers: The Politics of Play in Military Video Games, edited by Nina B. Huntemann and Matthew T. Payne, 106-121. New York, NY: Routledge.

Takacs, Stacy. 2012. Terrorism TV: Popular Entertainment in Post-9/11 America. Lawrence, KS: University Press of Kansas.

Tanine, Allison. 2010. The World War II Video Game, Adaptation, and Postmodern History. Literature/Film Quarterly 38(3): 183-193.

Tau, Byron. 2012. John Brennan: Drones 'necessary,' not 'vengeance.' Politico. Accessed November 15, 2012. http://www.politico.com/news/stories/0412/75751.html

Terkel, Amanda. 2013. Distinguished Warfare Medal Honoring Drone Pilots Canceled By Chuck Hagel. The Huffington Post. Accessed February 27, 2014. http://www.huffingtonpost.com/2013/04/15/distinguished-warfare-medal_n_3086660.html

Thier, Dave. 2010. The Real Soldier Behind the 'Call of Duty' Games. AOL News. Accessed November 15, 2012. http://www.aolnews.com/2010/10/19/the-real-soldier-behind-the-call-of-duty-games/

Wall, Tyler and Torin Monahan. 2011. Surveillance And Violence From Afar: The Politics Of Drones and Liminal Securityscapes. Theoretical Criminology 15(3): 239-254. 